Cell Research (2003); 13(5):319-333

http://www.cell-research.com

\title{
Methylation profiling of twenty four genes and the concordant methyla- tion behaviours of nineteen genes that may contribute to hepatocellular carcinogenesis
}

\author{
JiAn YU ${ }^{1 *}$, Hong Yu ZHANG ${ }^{1 *}$, Zhen Zhong MA ${ }^{1}$, Wei LU ${ }^{2}$, Yi FeI WANG ${ }^{2}$, JingDe ZHU ${ }^{1 * *}$ \\ 1 The State-Key Laboratory for Oncogenes and Related Genes, Shanghai Cancer Institute, Shanghai Jiaotong University, \\ LN 2200/25, Xietu Road, Shanghai 200032,ChinaE-mail: zhujingde@yahoo.com \\ 2 Department of Mathematics, Shanghai University, No. 99, Shangda Road, Shanghai 200436, China
}

\begin{abstract}
To determine the possible role of the epigenetic mechanisms in carcinogenesis of the hepatocellular carcinoma, we methylation-profiled the promoter $\mathrm{CpG}$ islands of twenty four genes both in HCC tumors and the neighboring non-cancerous tissues of twenty eight patients using the methylation-specific PCR (MSP) method in conjunction with the DNA sequencing. In comparison with the normal liver tissues from the healthy donors, it was found that while remained unmethylated the ABL, CAV, EPO, GATA3, LKB1, NEP, NFL, NIS and p2 $7^{\text {KIP1 }}$ genes, varying extents of the HCC specific hypermethylation were found associated with the ABO, AR, CSPG2, cyclin a1, DBCCR1, GALR2, IRF7, MGMT, MT1A, MYOD1, OCT6, p57 ${ }^{\mathrm{KIP} 2}$, p73, WT1 genes, and demethylation with the MAGEA1 gene, respectively. Judged by whether the hypermethylated occurred in HCC more frequently than in their neighboring normal tissues, the hypermethylation status of the AR, DBCCR1, IRF7, OCT6, and p73 genes was considered as the event specific to the late stage, while that the rest that lacked such a distinguished contrast, as the event specific to the early stage of $\mathrm{HCC}$ carcinogenesis. Among all the clinical pathological parameters tested for the association with, the hypermethylation of the cyclin a1 gene was more prevalent in the non-cirrhosis group $(\mathrm{P}=0.021)$ while the hypermethylated $\mathrm{p} 16^{\mathrm{INK} 4 \mathrm{a}}$ gene was more common in the cirrhosis group $(\mathrm{P}=0.017)$. The concordant methylation behaviors of nineteen genes, including the four previously studied and their association with cirrhosis has been evaluated by the best subgroup selection method. The data presented in this report would enable us to shape our understanding of the mechanisms for the HCC specific loss of the epigenetic stability of the genome, as well as the strategy of developing the novel robust methylation based diagnostic and prognostic tools.
\end{abstract}

Key words: promoter $C p G$ island, methylation specific PCR, concordant behaviors of methylation.

\section{INTRODUCTION}

Hepatocellular carcinoma(HCC) is one of the commonest cancerous diseases, rating the fifth in occurrence and the third in mortality worldwide[1]. As it is geographically biased toward the several parts of Asia and Africa, China in particular, it presents one of the major health threat in China[2,3]. The dismal prognostic future of the patients is largely attributive to the rapidly advancing nature and difficulties in early diagnosis of HCC. Therefore, there are urgent needs for the robust

*Both authors contribute equally to this work.

**Correspondence to: Jing De ZHU

Tel/Fax: 008621- 64224285; diagnostic, prognostic and even therapeutic approaches that can only be brought about by the much improved understanding of the fundamental aspects at various biological levels of the events during the malignant transformation of the normal hepatocytes. The decades of intensive molecular genetic analyses have yielded a considerable amount of information on the potential genetic defects associated with the natural course of carcinogenesis of hepatocytes[4-6]. Until recently, the epigenetic mechanisms without the changes in DNA sequence has been found capable of profoundly affecting the transcription status of both genes and repetitively sequences, that subsequently confers the growing advantage to tumor cells over their normal counterparts[7-9]. The co- 
valent addition of the methyl group at the $\mathrm{C} 5$ of cytosine in the $\mathrm{CpG}$ dinucleotide is essentially the only form of the covalent modification of DNA in high eukaryotes, having a number of biochemical as well as biological implications It can eliminate the sequence specific binding of the transcription factors to the cognate cis-elements and promote the association of the methyl $\mathrm{CpG}$ specific binding proteins to the methyl $\mathrm{CpG}$, with a cascade of reactions leading to the chromatin condensation and transcription silencing[10]. Over $50 \%$ of the protein coding genes have at least one $\mathrm{CpG}$ island within or near their promoters. Expressions of these genes are subjected to the controls over the methylation state of the $\mathrm{CpG}$ islands. Aberrant DNA methylation pattern changes the gene transcription and has been etiologically linked to the occurrence of a number of genetic diseases including cancers[10]. The enzymes responsible for DNA methylation are the DNA methyl transferase I and IIIA as well as IIIB. The former is mainly responsible for the maintenance of the methylation status of genomes after DNA replication, whereas the later two act principally in the de novo DNA methylation in the early development of high eukaryotic organisms[10]. Elevated expression of these three methyl transferase genes were reported in the majority of cancers tested, which may partly account for the increased local hypermethylation[10-12]. However, recent evidences demonstrated that the histone modification, methylation of histone $\mathrm{H} 3$ in particular, might occur prior to the establishment of the DNA hypermethylation pattern that contribute to the long-term silencing of gene transcription[13].

Changes in the DNA methylation patterns demonstrated in all the cancers examined, consist of the global level hypomethylation in parallel with the local hypermethylation[12,14]. The genome-wide hypomethylation can result in active transcription of the transposon like repetitive sequences (such as the Alu and LINE repeats in mammals) that have been linked to the increased genome instability, a predominant hallmark of cancer cells[15-17]. The hypermethylated status of the promoter $\mathrm{CpG}$ islands has been linked to the expression silencing of the tumor suppressor genes and implicated as the $2^{\text {nd }}$ hit, reminiscent to the loss of heterozygosity or other type of genetic deletion for total inactivation of the tumor suppressor genes in cancers [18-21]. The loss of the genetic imprinting attributed to the changes of DNA methylation, such as reactivation of the IGF-2 gene, has been linked to the rapid proliferation of tumor cells in several types of human tumors[22]. The reverse process, i.e.,demethylatin can also result in the transcription activation of the otherwise inert genes, including c-myc, and c-ras, even though all of these genes lack the typical $\mathrm{CpG}$ island within or near to the promoters[23]. The association between the hypomethylation of the promoter $\mathrm{CpG}$ island and over-expression state of the genes such as SURVIVIN[24] and hTERC that encodes the RNA component of the telomerase[25] have been recently reported.

Methylation profiling of the promoter $\mathrm{CpG}$ islands of the known genes has been an important information gathering process for new insights in our understanding of the mechanisms of the DNA methylation in both initiation and progression of the carcinogenesis, as well as the new clues for development of the relevant diagnostic and prognostic methods and even for therapeutics against cancers. The recent collective efforts have identified a list of over one hundred genes, the promoter $\mathrm{CpG}$ islands of which change in various tumors (http://www.missouri. edu/ hypermet/list_of_promoters.htm). However, as the majority of the studies to date had only targeted one or a few genes in rather small patient groups, the concurrent hypermethylation behavior of multiple genes has only been addressed in few tumor types, except for very few examples[26]. Prior to our recent work[27] where methylation profile of the promoter $\mathrm{CpG}$ islands of twenty genes in twenty nine HCC patient samples were presented, there had been only two reports describing the HCC specific change in the methylation profiling of three tumor suppressor genes: $\mathrm{p} 16^{\mathrm{INK} 4 \mathrm{a}}$, cyclin-dependent kinase inhibitor $4 \mathrm{~b}\left(\mathrm{p} 15^{\mathrm{INK} 4 \mathrm{~b}}\right)$ and the alternative reading frame of the cyclin-dependent kinase inhibitor $4 \mathrm{a}\left(\mathrm{p} 14^{\mathrm{ARF}}\right)$, respectively. In that study we found that sixteen genes adenomatosis polyposis coli (APC), apoptotic protease activating factor (APAF1), breast cancer 1 (BRCA1), cadherin type 1 (CDH1), death-associated protein kinase 1 HCC (DAPK1), mutL homolog 1 (hMLH1), Telomerase RNA component (hTERC), p14 ${ }^{\mathrm{ARF}}, \mathrm{p} 15^{\mathrm{INK} 4 \mathrm{~b}}$, phosphatase and tensin homolog (PTEN), ras association domain family 1 protein isoform 1c (RASSF1c), retinoblastoma 1 (RB1), retinoic acid receptor, beta (RARb), SURVIVIN, tissue inhibitor of metalloproteinase 3 (TIMP3) and von Hippel-Lindau syndrome (VHL) remained unmethylated in all the sample tested, whereas the following four genes: Caspase 8 (CASP8), H-cadherin (CDH13), p16 ${ }^{\mathrm{INK} 4 \mathrm{a}}$ and RASSF1a genes displayed the $\mathrm{HCC}$ associated hypermethylation to varying extents. The 
lack of the HCC specific changes in the sixteen of the twenty genes whose hypermethylation state of the promoter $\mathrm{CpG}$ island has been linked to many other types of cancer[27] was indeed a surprise. In order to establish the concordant methylation behavior of the genes displaying the HCC specific changes, we further extended our study to other twenty four genes to assess the extent of the methylation mediated mechanisms in the HCC and found fifteen genes had displayed the HCC specific changes. By the stringent mathematic analyses of the concordant methylation behaviors of the nineteen genes (including the four in the previous study[27]), the subsets of the two to nine genes have been established in HCC and its cirrhosis/non-cirrhosis subgroups, which may provide the useful clues for the DNA methylation based diagnostic and prognostic assays for HCC.

\section{MATERIALS AND METHODS}

\section{Tissue samples and DNA extraction}

With the informed consent of all patients and donors and approval of the ethics committee, the samples of tumor and adjacent noncancerous tissues were collected from HCC patients $(n=28)$ during surgery at The Qidong County Hospital, The Oriental Institute for Liver Diseases and Guangxi Provincial Hospital, respectively. In addition, normal liver tissues $(\mathrm{n}=4)$ were obtained from liver donors at the Liver Transplantation Unit in The First Affiliated Hospital, College of Medicine, Zhejiang University. The pathological classification of HCC tissues was carried out and the stage of each HCC was determined according to criteria outlined by the Liver Cancer Study Group of Japan[28]. Special efforts were made to include the corresponding non-cancerous tissues, samples of which were overlooked in all previous studies of HCC[24]. Furthermore, pathological examination of the tissues had been carried out to eliminate samples in which contamination of undesirable tissues exceeded $20 \%$. To emphasize the HCC specificity of this study, normal liver tissues from four male healthy donors were collected from the Liver Transplantation Unit of the Zhejiang First Hospital as the normal liver control.

Total genomic DNA was extracted from frozen tissue specimens (50-100mg) according to standard protocol with some modifications [27]. Frozen pulverized powders of the specimens were re-suspended with $2 \mathrm{ml}$ lysis buffer: $50 \mathrm{~m} M$ Tris-HCl pH 8.0, $50 \mathrm{mM}$ EDTA, 1\% SDS, $10 \mathrm{mM} \mathrm{NaCl}$ plus $100 \mathrm{mg} / \mathrm{ml}$ boiling-treated RNase A (Sigma). Following one hour of incubation at $37^{\circ} \mathrm{C}$, Proteinase K (Roche, USA) was added to the cellular lysates for a final concentration of $100 \mathrm{mg} /$ $\mathrm{ml}$ and the digestion was carried out at $55^{\circ} \mathrm{C}$ for $2 \mathrm{~h}$. Organic extractions with a half volume of Phenol/Chloroform/Isoamyl alcohol (1:1:0.04) were repeatedly carried out until no visible interphase remained after centrifugation. DNA was precipitated from the aqueous phase in the presence of $0.3 \mathrm{MNaOAc} \mathrm{pH} 7.0$ and two and a half volumes of ethanol. The DNA pellet was washed once with $70 \%$ ethanol and dissolved at $65^{\circ} \mathrm{C}$ for $30 \mathrm{~min}$ with $0.2-0.4 \mathrm{ml}$ TE $(10 \mathrm{mM}$ Tris- $\mathrm{HCl} \mathrm{pH} 7.4$ and $1 \mathrm{mM}$ EDTA), followed by storage at $4{ }^{\circ} \mathrm{C}$ until further use. The DNA concentrations were calculated according to their OD260nm readings.

\section{Bisulphate treatment of DNA and methylation spe- cific PCR (MSP)}

The primer pairs for the methylation specific PCR in this report were either adopted or designed according to the same principle with assistance of the software packages for the $\mathrm{CpG}$ islands identification (http://www.uscnorris.com/cpgislands) and the primer design (http:/ /micro-gen.ouhsc.edu/cgi-bin/primer3_www.cgi)

The methylation status of the promoter $\mathrm{CpG}$ islands of twenty four genes in all sample DNA were analyzed by MSP on the sodiumbisulfite converted DNA [27]. In detail, $10 \mathrm{mg}$ DNA in $50 \mathrm{ml}$ TE was incubated with $5.5 \mathrm{ml}$ of $3 \mathrm{M} \mathrm{NaOH}$ at $37^{\circ} \mathrm{C}$ for $10 \mathrm{~min}$, followed by a 16 hour treatment at $50{ }^{\circ} \mathrm{C}$ after adding $30 \mathrm{ml}$ of freshly prepared 10 $\mathrm{mM}$ hydroquinone and $520 \mathrm{ml}$ of freshly prepared $3.6 \mathrm{M}$ sodiumbisulfite at $\mathrm{pH}$ 5.0. The DNA was desalted using a home-made dialysis system with $1 \%$ agarose (detailed protocol will be provided upon request). The DNA in the desalted sample (approximately $100 \mathrm{ml}$ in volume) was denatured at $37^{\circ} \mathrm{C}$ for $15 \mathrm{~min}$ with $5.5 \mathrm{ml}$ of $3 \mathrm{M}$ $\mathrm{NaOH}$ followed by ethanol precipitation with $33 \mathrm{ml} 10 \mathrm{MNH} 4 \mathrm{OAC}$ and $300 \mathrm{ml}$ ethanol. After washing with $70 \%$ ethanol, the gently dried DNA pellet was dissolved with $30 \mathrm{ml} \mathrm{TE}$ at $65^{\circ} \mathrm{C}$ for $10 \mathrm{~min}$. The DNA sample was finally stored at $20{ }^{\circ} \mathrm{C}$ until further use. PCR reaction was carried out in a volume of $15 \mathrm{ml}$ with $50 \mathrm{ng}$ or less template DNA with FastStart Taq polymerase (Roche, Germany) as follows. After an initial heat denaturing step 4 min treatment at $94^{\circ} \mathrm{C}, 30$ cycles of $92^{\circ} \mathrm{C}$ for $15 \mathrm{sec}$, varying temperatures with primer pairs for $15 \mathrm{sec}$ and 72 ${ }^{\circ} \mathrm{C}$ for $20 \mathrm{sec}$, was carried out. The PCR products were separated by $1.2 \%$ ethidium bromide containing agarose gel electrophoresis with 1 $\mathrm{X}$ TAE and visualized under UV illumination. To verify the PCR results, representative bands from each target were gel-purified and cloned into T-vector (Promega, USA) followed by automatic DNA sequencing provided by BoCai (Shanghai, China). Only verified results were presented in this report.

\section{Statistics}

The methylation data were dichotomized as 1 for the co-existence of the methylated and unmethylated alleles, 2, for methylated allele only and 0 for the unmethylated for both alleles to facilitate statistical analysis using contingency tables. The methylation profiles of each individual gene (in percentage) classified by the cirrhosis status of the patients were presented both in table and in plot. The statistic analyses for the association between the methylation profile of the gene and each of the clinical-pathological parameters were carried out with the statistics package (http://www.R-project.org/), where both Pearsong's Chi-square test with Upton's adjustment and Fisher exact test (http://www.R-project.org/) used to deal with the sample cells with the low expected values. The relative frequency with a $95 \%$ confidence interval $(\mathrm{P}<0.05)$ for a binomial distribution was calculated for the whole as well as each subtypes of astrocytoma patients.

The concordant methylation behaviors of the genes were established by comparing the relevant occurrence of various subsets containing two, three and four genes respectively, with the best sub-set selection method[29]. 
Tab 1. The target promoter $\mathrm{CpG}$ islands and the primers for MSP

\begin{tabular}{|c|c|c|c|c|c|}
\hline Gene Name & GeneBank No. & Sense $5^{\prime}-3^{\prime}$ & Antisense $5^{\prime}-3^{\prime}$ & Genomic position & Size (bp) \\
\hline ABL (M) & U07563 & CGAGGATCGTTATTGGTTCG & TAACCGAAACGCGCCTATTA & -368 to -172 & 197 \\
\hline $\mathrm{ABL}(\mathrm{U})$ & & TTGTTATTGGTTTGGGTTGG & TAACCACAACCACATCTCCAC & -362 to -150 & 213 \\
\hline $\mathrm{ABO}(\mathrm{M})$ & U22302 & TTAAGGTATTAGGGTTACGAGGGGC & CGACCATAACTCCGCGTCT & -243 to +6 & 250 \\
\hline $\mathrm{ABO}(\mathrm{U})$ & & GGATAGGGTTTTAAGGTATTAGGGTT & CСАCATCTAATCTCAACCTCCA & -253 to -5 & 249 \\
\hline AR (M) & M58158 & TTTCGAGATTTCGGGGAG & ACAACTCCGAACGACGAC & -3 to +210 & 214 \\
\hline $\operatorname{AR}(U)$ & & TTTTGAGATTTTGGGGAGTTAG & CCAAACAACAACTTCAAAACCA & -3 to +204 & 208 \\
\hline CAV (M) & NT_007933 & TTAGGGCGAGAGCGATTC & GCCGCCAAAAATCAAAAC & +1320 to +1482 & 163 \\
\hline $\mathrm{CAV}(\mathrm{U})$ & & AGTGTTTAGGGTGAGAGTGATTTG & CCACCCACCACCAAAAAT & +1315 to +1488 & 174 \\
\hline CSPG2 (M) & NT_007022 & AGTTTCGGGGGACGTTT & TTTTCTACCCCGCTCTCC & +1351 to +1526 & 177 \\
\hline CSPG2 (U) & & GAGTTTTGGGGGATGTTTTT & AACACCCAAACCACTCCA & +1350 to +1501 & 152 \\
\hline cyclin al $(\mathrm{M})$ & AF 124143 & TCGTCGCGTTTTAGTCGT & ACCCGTTCTCCCAACAAC & -755 to -550 & 206 \\
\hline cyclin al (U) & & GGGTAGTTTTGTTGTGTTTTAGTTG & AACCACTAACAACCCCCTCT & -762 to -565 & 199 \\
\hline DBCCRI (M) & AL138894 & CGGGTGTAGCGTTTCGTA & CAAAAACCСССТСССТАA & +396 to +561 & 166 \\
\hline DBCCR1(U) & & GGTGGTGTTGGGTGTAGTG & CAAAAACCCССТСССТАA & +388 to +561 & 174 \\
\hline EPO (M) & NT_007933 & TTTACGTTTCGGCGAGTT & CGAACGACCGAAATAACC & -212 to -28 & 185 \\
\hline EPO (U) & & TTTTGTTTATGTTTTGGTGAGTTTTA & ACCCCAATCCAACTCCAA & -217 to +17 & 236 \\
\hline GALR2(M) & NT_010641 & GTTTCGGCGCGTATTTTA & CACGCAAAATCCGAAATC & -400 to -246 & 155 \\
\hline GALR2(U) & & TGGAGTGGTTTTGGTGTGTAT & CAAAATCAACCCCTCCAC & -389 to -239 & 151 \\
\hline GATA3(M) & NT_033983 & GGTCGTACGTCGTCGTTT & AAAACACCGATCCCGAAA & -659 to -468 & 192 \\
\hline GATA3 (U) & & GATTGAGTAGGTTGTATGTTGTTGTTT & CCAATCCCAAAACCATCC & -668 to -474 & 195 \\
\hline IRF 7(M) & NT_008953.8 & GTTTCGCGGAGTTGAGAATC & TATAACCGACGCGCACAC & $+161 ?$ to +356 & 196 \\
\hline IRF 7 (U) & & GGTGGGGTTTTGTGGAGT & TACAAATATAACCAACACACACAC & +155 to +362 & 208 \\
\hline LKB1 (M) & XM_012913 & GGTGTTCGTCGGTTCGTA & TTCCGACTTCCCTTCTCC & -253 to -68 & 168 \\
\hline LKBI(U) & & TTTGGTGTTTGTTGGTTTGTA & TATATTCCAACTTCССТТСТСC & -238 to -64 & 175 \\
\hline MAGEA1 (M) & U82670 & GTTCGGTCGAAGGAATTTGA & CСАCAACCСТСССТCTTAAA & +24 ? to +345 & 322 \\
\hline MAGEA1 (U) & & GTTTGGTTGAAGGAATTTGA & ACCCACAACCCTCCСТCTТA & +24 to +347 & 324 \\
\hline MGMT(M) & AL355531 & AGCGTCGTTGTTTTGTGC & CGCTTTCAAAACCACTCG & -451 to -266 & 186 \\
\hline $\operatorname{MGMT}(\mathrm{U})$ & & TTGGTAGTGTTGTTGTTTTGTGT & CATCCTACAACCCCCACA & -469 to -261 & 209 \\
\hline MT1A (M) & K01383 & TAAGGTTGGGTTTTCGGAAC & AAATACGAACCACGAAACCA & -421 to -258 & 164 \\
\hline MTIA (U) & & TAAGGTTGGGTTTTTGGAAT & CTCСССТAAATACAAACCACA & -421 to -251 & 171 \\
\hline MYODI (M) & AF027148 & GACGGTTTTCGACGGTTT & GCCCGAAACCGAATACAC & +210 to +393 & 184 \\
\hline MYOD1 (U) & & ATTTGATGGTTTTTGATGGTTT & CACACACATACTCATCCTCACA & +206 to +418 & 213 \\
\hline NEP (M) & X79438 & GGTGTTTCGTCGTTTTACG & CATCCCGACCAATAAACG & $+3592 ?$ to +3760 & 169 \\
\hline NEP (U) & & GTTTAGGTGTTTTGTTGTTTTATGG & CCAACACATCCCAACCAAT & +3587 to +3766 & 180 \\
\hline NFL $(M)$ & $\mathrm{X} 05608$ & TTTATTGGTCGGCGTGTC & TACTCCCCGACGACGAT & -81 to +81 & 163 \\
\hline NFL(U) & & TGTTTTTATTGGTTGGTGTGTT & ACATCTCCACATAACACCACTT & -85 to +159 & 245 \\
\hline NIS (M) & $\mathrm{AC} 005796$ & GTTTCGTTGCGGTCGT & TACCGCACGTCCATTAACT & -12279 to -12115 & 165 \\
\hline NIS (U) & & ATGTTTTGTTGTGGTTGTGGT & ACACATCCATTAACTTCTCTACCC & -12281 to -12119 & 163 \\
\hline OCT6 (M) & L26494 & ACGAGGATGCGTTTAGTTCG & GAATCGATCTCCTCCAACCA & +727 to +955 & 229 \\
\hline OCT6 (U) & & GGATGAGGATGTGTTTAGTTTG & TCAATCTCCTCCAACCACTT & +725 to +952 & 228 \\
\hline $\mathrm{p} 27^{\mathrm{KIPI}}(\mathrm{M})$ & AB 003688 & CGACGTCGGTAAGGTTTG & AAACGCGCAAAAACTACG & -355 to -163 & 193 \\
\hline p27 $7^{\text {KIPI }}(U)$ & & TGTGATTTTGATGTTGGTAAGGT & CAAACCACAACCCAAACTCT & -363 to -141 & 223 \\
\hline $\mathrm{p} 57^{\mathrm{k} 112}(\mathrm{M})$ & HSU48869 & GGGTTCGCGCGTATAAA & ATACGAAAAACGCGACGA & -70 to +118 & 205 \\
\hline $\mathrm{p} 57^{\mathrm{KIP} 2}(\mathrm{U})$ & & GGGTGGGGTTTGTGTGTAT & AAACACAACAACTACCTAACTATC & -79 to +111 & 203 \\
\hline p73 (M) & AB031234 & GCGTTCGGTTCGTAGGTT & CTCAACTCCCAAAACCCAA & -1722 to -1511 & 212 \\
\hline p73 (U) & & TGGGTGTTTGGTTTGTAGGT & ССААСТСТСААСТССCAAAA & -1725 to -1505 & 221 \\
\hline WT1(M) & X74840 & GTTAGGCGTCGTCGAGGTTA & AAAACGCAAAATCCAACACC & +321 to +526 & 206 \\
\hline WT1 (U) & & TGGGATTTGGGTGGTATTTG & CACCAACACCCACTACACCA & +295 to +510 & 216 \\
\hline
\end{tabular}

\section{RESULTS AND DISCUSSIONS}

\section{Clinical-pathological considerations}

The geographical distribution of HCC varies dramatically in China. In areas such as Qidong county near Shanghai as well as Guangxi province, the annual HCC incidence is as high as $70-96 / 10,0000$ and approximately seven to eight fold higher than that in the low incidence areas in China[30]. In view of the high likelihood of the potential geographic impact, we deliberately recruited nineteen patients in the Shanghai area, including eight patients from Qidong County, and nine patients from Guangxi province. All the patients were hepatitis B virus (HBV) infected by both immuno-serological assays and the PCR test for existence of the HBVX gene in tumor tissue (result not shown). No geographical variation is detected between these two patient groups. For instance, male patients accounted for $78.9 \%$ and $80 \%$, cirrhosis occurred in $52.6 \%$ and $50 \%$ of patients and diagnoses 
of grade I were $28 \%$ and $30 \%$, grade II were $44 \%$ and $40 \%$ and grade III were $28 \%$ and $30 \%$ of the Shanghai and Guangxi patient groups, respectively[27]. Therefore, the remaining analyses were carried out without any consideration of geographic impact.

\section{Methylation profiling}

The methylation specific PCR (MSP) on the bisulphate treated DNA has been widely used for its simplicity as well as speed. In the previous work, we verified the MSP data by sequencing the representative PCR products and validated the data of two among twenty genes studied with a non PCR mediated method, i.e., Southern analyses of the DNA digests by the methylation sensitive enzymes[27]. In this extended study, therefore, the MSP in conjunction with the DNA sequencing of the batchtreated genomic DNA from the same patient group and the normal control was adopted.

The in vivo malignant transformation of normal cells is a multiple-stage process, involving at least a dozen of genetic and epigenetic changes. In this connection, there is a prevalent notion that the morphologically "normal" cells adjacent to the cancerous tissues may have already suffered from the genetic or/and epigenetic changes that are specific to the early phase of malignant transformation. To take this favorable assumption into account, we deliberately recruited, both in this report and the previous, the neighboring non-cancerous liver tissues in addition to HCC tissues into study, which have been often excluded in other similar studies([27] and references within).

The concerns were fully justified as to the crosscontamination of the normal tissue in the HCC samples, or vice versa. However, this seemed unfounded in our studies. First, over forty four genes (twenty four genes were in this study and twenty genes were in the previous report[27]), were chemically treated in batch and methylated profiled in group. The obtained well diversified methylation patterns of these forty four genes are fully incompatible with the assumption that there may be the severe cross-contamination of the undesirable tissues in the designated samples. Second, MSP is a sensitive method capable of detecting a very low level of contamination of the undesirable DNA. Thirdly, in addition to the sequencing verification, the HCC specific methylation profile of the p14ARF and p15INK $4 \mathrm{~b}$ genes had been confirmed by a non-PCR based Southern analysis of the digested DNA with the methylation sensitive restriction enzymes[27].

Another issue of importance is concerning the methylation heterozygosity in any given samples. As shown the Fig 1 and Tab 2, although some samples were homozygously methylated or unmethylated, the majority had the co-existed methylated and unmethylated alleles. Inclusion of the normal liver tissues in our study enabled us to establish the normal methylation pattern of all the forty four genes, that except for the MAGEA1[31] being homozygously methylated, the rest forty three were homozygously demethylated[27] (Fig 1 and Tab 2). Therefore, any changes in the methylation pattern from the normal liver tissue's to the non-cancerous neighboring tissues or HCC tissues should indicate the involvement of the DNA methylation mediated events during the HCC carcinogenesis, that have been scored as the positive methylation change. Whether the alleles lacking in HCC specific methylation change may lose its function via the genetic mechanisms remains to be addressed in the future.

The in vivo malignant transformation of normal cells is a multiple-stage process, which involves multiple genetic and epigenetic changes. In this connection, it has been generally accepted that the morphologically "normal" cells adjacent to the cancerous tissues may have already been abnormal at both genetic and epigenetic levels, reflecting the early-phase-specific alteration of the malignant transformation. We, hence, recruited the neighboring non-cancerous liver in addition to $\mathrm{HCC}$ tissues, to address the stage-specific nature of the methylation changes that are likely to be reflected in the neighboring non-cancerous and HCC tissues, respectively.

\section{Methylation profiling of twenty four genes with or} without the proven roles in carcinogenesis of the hu-

\section{man cancers}

The consequence of the tumor-specific defects in the epigenetic homeostasis is global, and some detectable changes may have etiological role to play whereas others may simply the by-stander by nature. Therefore, from the list of the promoter CpG island containing genes (http:/ /www.missouri.edu/ hypermet/list_of_promoters.htm) we deliberately selected the targets that lack any proven etiological role in carcinogenesis of other tissue origins, 
The former group consisted of the genes encoding the growth factor for the erythropoiesis (EPO) [32], a ubiquitously expressed transcription factor (OCT6)[33], the blood cell typing antigen (ABO) [34], and the myogenetic or erythropoietic lineage-specific transcription factors (MYOD1 of GATA3)[35] [36] as well as the light chain of neurofilament (NFL)[37]. In the second group, there were four tumor suppressor genes, including two cyclindependent kinase inhibitors: p27KIP1 [38]and p57KIP2 [39]; p53 analogue, p73[38,40], as well as the Wilms tumor 1 gene, WT1. There were seven genes encoding the surface proteins or nuclear receptors acting actively in the intercellular interactions: galanin receptor 2 (GALR2)[42], melanoma specific antigen A1 (MAGEA1), the membrane metallo-endopeptidase (NEP) [43], solute carrier family 5 (NIS) [44], caveolin 1 (CAV) [45], chondroitin sulfate proteoglycan 2 (CSPG2) [46] and androgen receptor (AR)[47]. Three genes implicated in signal transduction, cyclin a1[48], the interferon regulatory factor 7 (IRF7), and a serine/threonine kinase 11 (Peutz-Jeghers syndrome) gene (LKB1)[18] were selected. The proto-oncogenes in this group were: the gene encoding v-abl homologue 1 (ABL)[49] and for the deleted in bladder cancer chromosome region candidate 1 (DBCCR1)[50]. The final two in the list were the genes that may be responsible for detoxification of liver cells: O-6-methylguanine-DNA methyltransferase (MGMT) [18] and metallothionein 1 A gene (MT1A)[51].

As shown in Fig 1 and Tab 2, within the group of genes maintaining unmethylated in all three types of samples tested, there are the genes devoid of any demonstrated association with tumors: EPO(panel 8), GATA3(panel 10), NFL(panel 18) and NIS(panel 19), as well as the genes having the demonstrated hypermethylation mediated gene silencing in the human tumors of the non-HCC origins: ABL(panel 1), CAV(panel 4), LKB1(panel 12), NEP (panel 17), and p27KIP1(panel 21) genes. The simplistic explanation would be that either inactivation of these genes in $\mathrm{HCC}$ via the genetic based mechanisms, or HCC formation does not require the functional inactivation of these genes.

The genes with the HCC specifically altered methylation profiles

Fourteen genes: ABO(panel 2), AR(panel 3), CSPG2 (panel 5), cyclin a1(panel 6), DBCCR1(panel 7), GALR2 (panel 9), IRF7(panel 11), MGMT(panel 14), MT1A (panel 15), MYOD1(panel 16), OCT6(panel 20), p57KIP2 (panel 22), p73(panel 23), and WT1(panel 24) were unmethylated in all four cases of the normal liver tissues, and methylated to various extents in the patient's samples. Among them, there were the genes devoid of any obvious tumor association: 1, ABO (transferase A for the ABO blood typing), 2, MYOD1 (the myogenic specific transcription factor), and 3, OCT6 (a common transcription factor with POU domain). The hypermethylation frequency was as higher as 32\%(9/28) and 50\%(14/28) for ABO gene, 54\%(15/28) and 54\%(15/28) for MYOD1, as well as $50 \%(14 / 28)$ and $82 \%(23 / 28)$ for OCT6 gene in the non-cancerous neighboring liver and HCC tissue, respectively. Despite the higher incidence of changes in the methylation profile, it is not possible to discard the possible by-stander nature of such alterations (Fig 1 and $\mathrm{Tab} 2$ ). There were suggestions for the possible aging related increase in the promoter $\mathrm{CpG}$ island of the genes including OCT6 and MYOD1[52,53], However, it seems not the case in this study as there was no obvious correlation between the age of the HCC patients and the occurrence of the methylated status of the promoter $\mathrm{CpG}$ island. Alternatively, likely loss of these three gene expression (extrapolated from the hypermethylated status of the relevant promoter $\mathrm{CpG}$ islands) indeed play some parts in the HCC formation in the unknown manners, which may deserve the further investigation.

The rest are the genes implicating in the human tumors of other tissue origins via the methylation mediated gene silencing(http://www.missouri.edu/ hypermet/ list_of_promoters.htm): AR(panel 3), CSPG2(panel 5), cyclin a1 (panel 6), DBCCR1(panel 7), GALR2(panel 9), IRF7(panel 11), MGMT(panel 14), MT1A(panel 15), p57KIP2(panel 22), p73(panel 23), and WT1 (panel 24)\} or demethylation mediated activation: MAGEA1(panel 13). Among these targets, the MGMT gene was rarely methylated ( $3.57 \%, 1 / 28)$. It encodes the enzyme capable of removing the alkylating adducts from the $\mathrm{O}(6)$ position of guanine and protects the cells from cytotoxic and mutagenic effects [20]. The MT1A gene that encodes the protein responsible for the cell detoxification targeting at various adversary stimuli including the heavy metals, has been reported being inactivated by the hypermethylated promoter $\mathrm{CpG}$ island in rat hepatoma [51]. It was only marginally hypermethylated in HCC $(10.71 \%, 3 / 28)$, indicating that the DNA methylation 


\section{Panel 1}

ABL

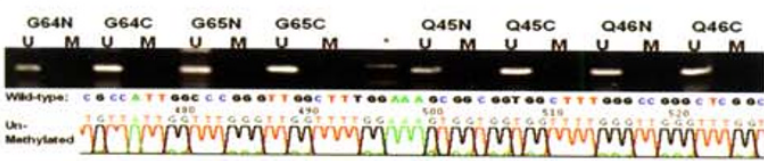

\section{Panel 3}

AR

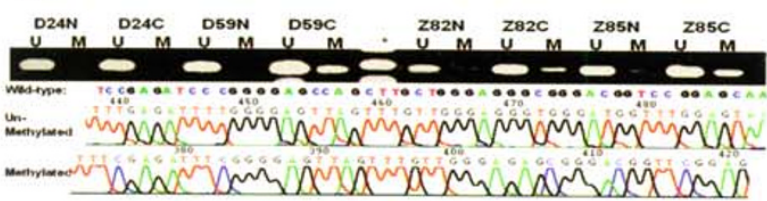

Panel 5

CSPG2

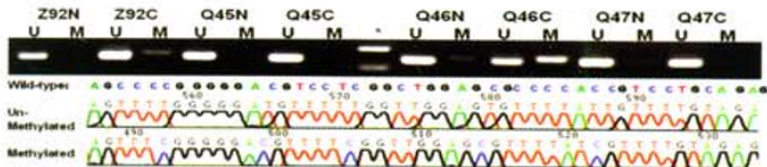

Panel 7

DBCCR1

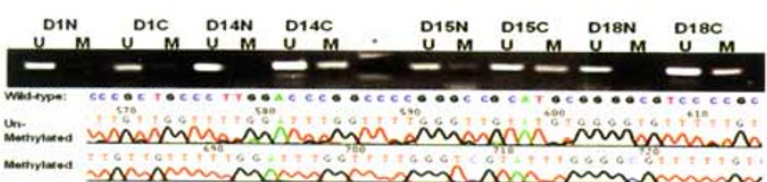

Panel 9

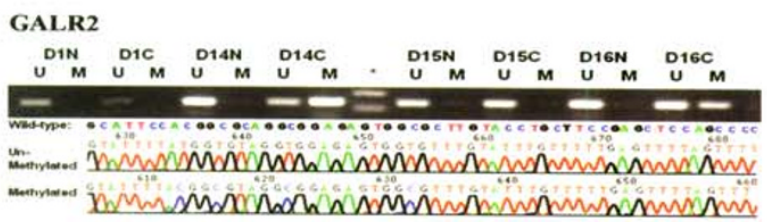

Panel 11

IRF7

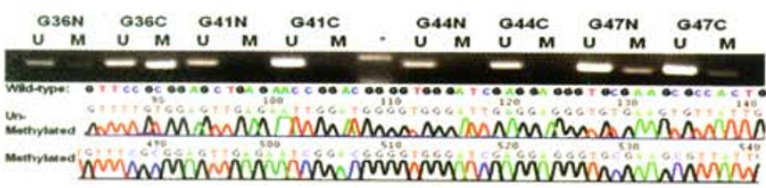

\section{Panel 13}

\section{MAGEA}

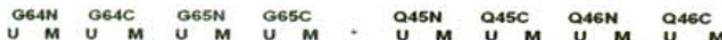
- $-1--$ - --

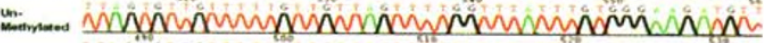

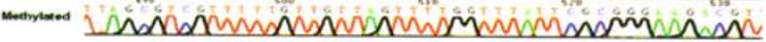

\section{Panel 2}

\section{ABO}

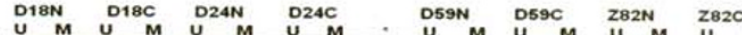

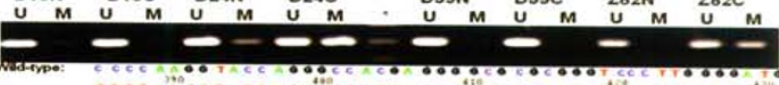

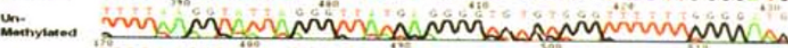

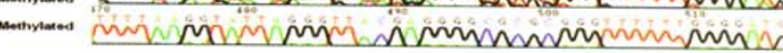

\section{Panel 4}

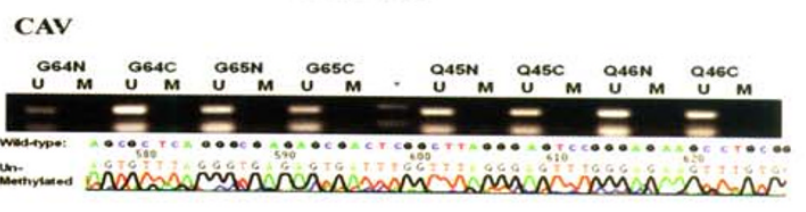

\section{Panel 6}

cyclin a1

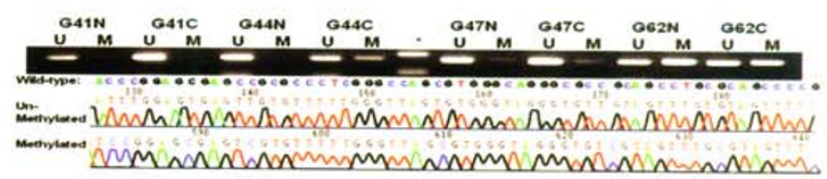

EPO

\section{Panel 8}

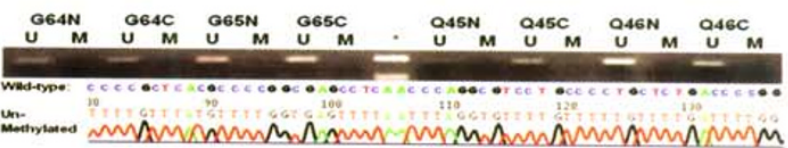

\section{Panel 10}

GATA3

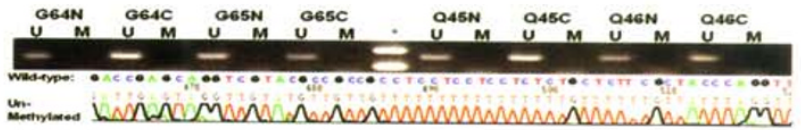

\section{Panel 12}

\section{LKB1}

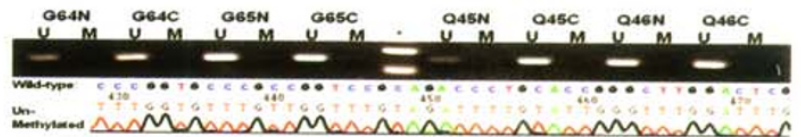

\section{Panel 14}

\section{MGMT}

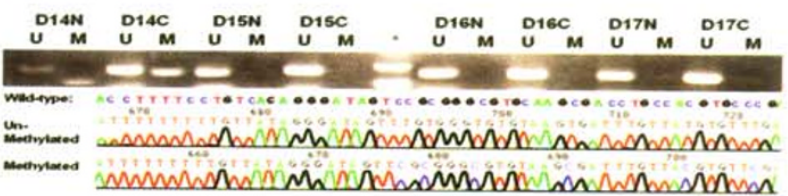




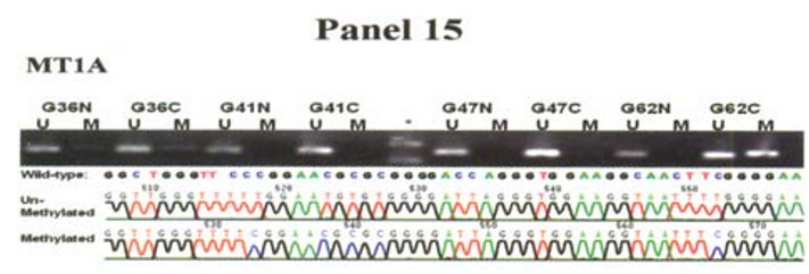

Panel 17

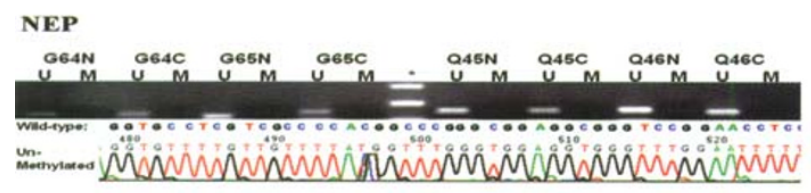

Panel 19

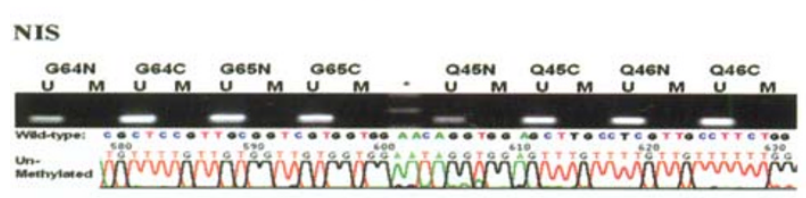

Panel 21

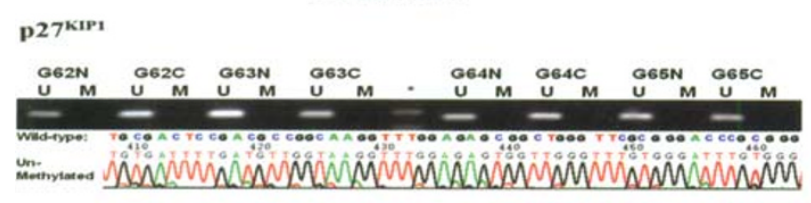

Panel 23

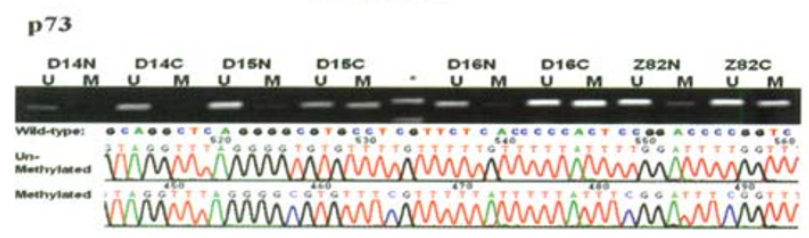

\section{Panel 16}

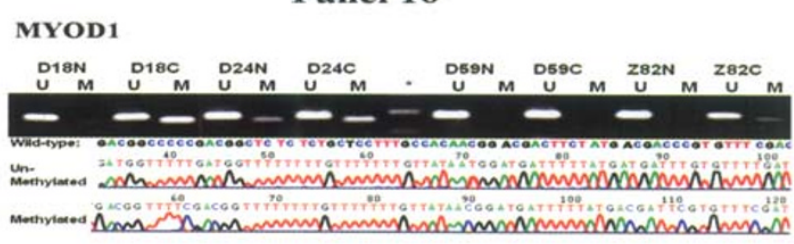

Panel 18

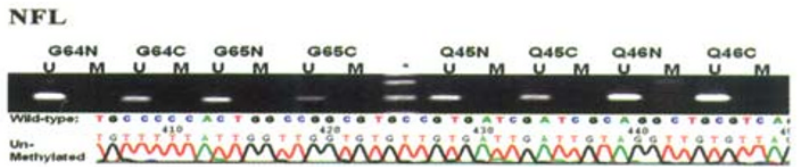

Panel 20

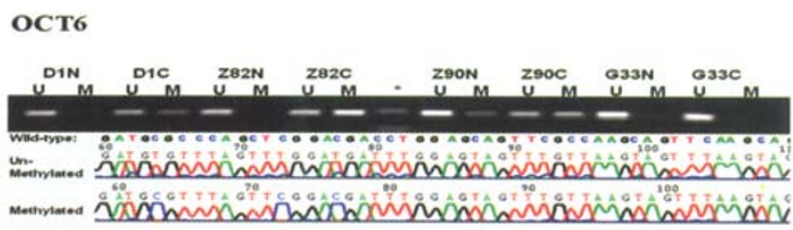

Panel 22

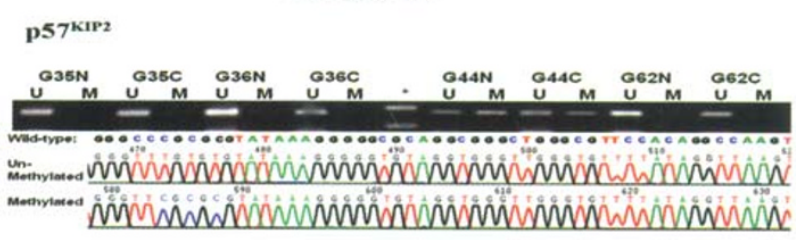

Panel 24

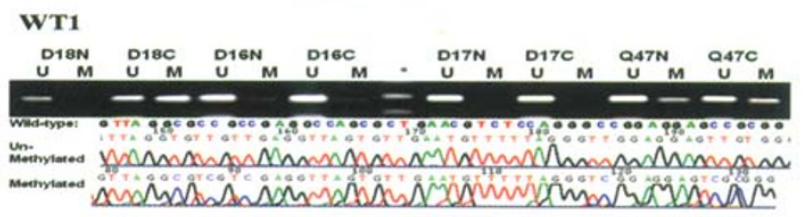

Fig 1. Methylation profiles of the promoter $\mathrm{CpG}$ islands of twenty four genes in HCC. Both electrophoretic patterns of the representative PCR products of each of twenty four targets (indicated respectively, at the top of figures) and the sequencing verification of the one representative PCR product were presented. To indicate the methylation status, the sequenced data are aligned with the wild-type sequence. ", size markers, the bands of $250 \mathrm{bp}$ and $100 \mathrm{bp}$ were shown. U, the unmethylated; M, the hypermethylated. panels: 1, ABL; 2, ABO; 3, AR; 4, CAV; 5, CPSG2; 6, cyclin a1; 7, DBCCR1; 8, EPO; 9, GALR2; 10, GATA3; 11, IRF7; 12, LKB1; 13, MAGEA1; 14, MGMT; 15, MT1A; 16, MYOD1; 17, NEP; 18, NFL; 19, NIS; 20, OCT6; 24, 21, p27 ${ }^{\text {KIP1; }}$ $22, \mathrm{p} 57^{\mathrm{KIP} 2} ; 23, \mathrm{p} 73$ and 24 , WT1.

mediated mechanism should not play any significant role in its inactivation, if there is any, in HCC. The following three genes: CSPG2 (17.86\%), GALR2(21.43\%) and $\mathrm{p} 57^{\mathrm{KIP} 2}(14.29 \%)$ were moderately hypermethylated in HCC, expression of which may not be significantly affected by the DNA hypermethylation of their promoter $\mathrm{CpG}$ island in HCC.

The AR gene encodes the androgen receptor that play a key role in the signal transduction pathways of cells to respond to the male steroid hormone, androgen and was reported to be inactivated via the epigenetic mechanism in prostate cancers[54]. HCC seems an androgendependent tumor as it occurs five times more in males than that in the females. In this connection, a recent study reported that the AR gene was rarely expressed in the poorly differentiated HCC affecting the males[55]. This 


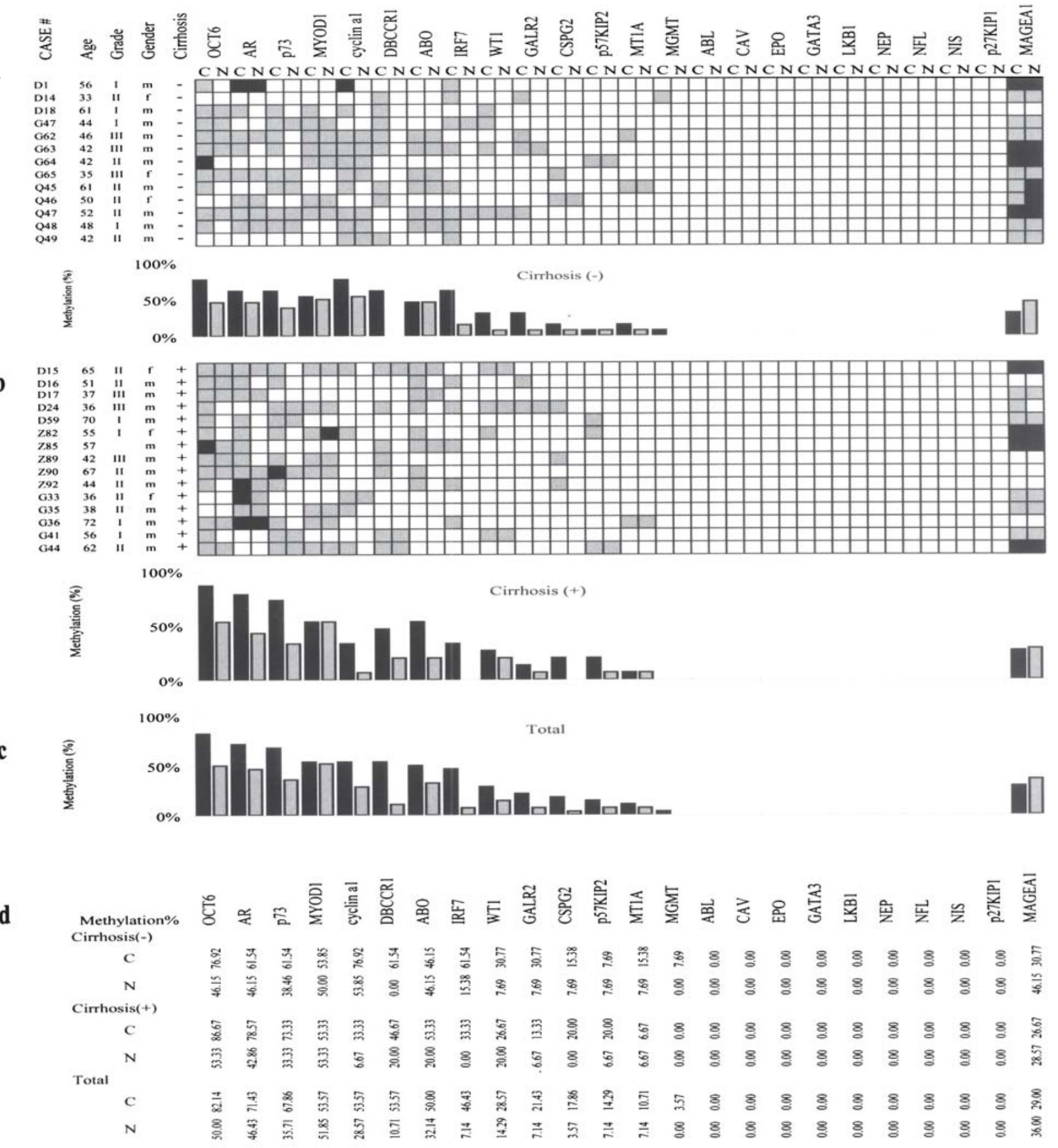

Tab 2. Summary of both occurrence and frequency of the hypermethylation for each genes in each of HCC patient samples along with some clinical-pathological parameters( age, gender, grading and cirrhosis). a), The non-cirrhosis patient group, b), the cirrhosis patient group, and c), the total patient group. The filled, shading and empty boxes indicate the cases where only hypermethylated, both hypermethylated and unmethylated and only unmethylated alleles were detected, respectively. The frequency (\%) of the hypermethylated targets (except for the MAGEA1, where the hypomethylated) among the total cases was calculated and presented in plot. The frequency of changes (\%) in the methylation pattern in $\mathrm{HCC}(\mathrm{C})$ and the neighboring non-cancerous tissues(N) against the normal healthy liver tissues were detailed in $\mathbf{d})$.

does correlate well with the observation in this study that there was high occurrence $(82.14 \%, 20 / 28)$ of the hypomethylation of the AR gene in the male HCC patient tissue. Although it was hypermethylated more fre- quently in the female $(83.3 \%, 5 / 6)$ than the male patient group $(68 \%, 15 / 22)$, the implication may be different. Loss of the hypermethylation of the AR gene in the females may symbolize the tumor associated defects in epige- 
netic control in general.

The DBCCR1 gene identified at the region (q32-q33) within chromosome $9 \mathrm{q}$ with high $\mathrm{LOH}$ in human bladder carcinoma is the most frequent genetic alteration in transitional cell carcinoma (TCC) of the bladder. Its loss of expression correlated well the hypermethylation of the promoter $\mathrm{CpG}$ island at a frequency as high as 52\% (36/ 69) bladder carcinoma[50]. In this study, the promoter $\mathrm{CpG}$ island has been detected at a comparable frequency $(53.57 \%)$, indicating its possible role in the HCC formation.

The p73 gene encodes a protein structurally and functionally homologous to TP53, and maps to chromosomal band $1 \mathrm{p} 36.33$, where loss of heterozygosity has been observed in up to $90 \%$ of oligodendrogliomas and in $10-25 \%$ of diffuse astrocytoma[56,57]. In this report, we found that the 73 gene was prevalently methylated $(68 \%)$ in HCC tissues. However, whether its hypermethy- lation correlates with its functional inactivation remain to be determined.

Both genetic defects and epigenetic abnormalities concerning the WT1 gene have been implicated in the formation of Wilm's tumor[58]. In this study, we also found the WT1 gene hypermethylated in $29 \%$ of the HCC cases, implying its possible involvement in the formation of HCC.

Resistance of tumors to the cytotoxic chemotherapies may result from the disrupted apoptosis programs and remains a major obstacle in cancer treatment. In this connection, the IRF7 gene was also analyzed, the analogue (IRF1) of which has been implicated in the IFN gammar mediated apoptosis with a profound impart to the chemo-sensitivity of the tumor cells[59,60]. The IRF7 expression was negatively regulated by the promoter methylation[61]. In this study, the IRF7 gene was hypermethylated in $46 \%$ of the HCC cases being studied, indicating the possible involvement of its inactivation by the hypermethylation in HCC.

\section{Hypomethylation of the promoter $C p G$ island of the} MAGEAl gene may be essential to its HCC specific expression

Although the hypermethylation mediated gene silencing of the tumor suppressor genes has caught the major attention, the local hypomethylation has also recently been linked to reactivation of transcription of the genes that are hypermethylated and silenced in the normal tissues
$[9,62]$. Therefore, we have also assessed whether the switching-on of the otherwise hypermethylated genes in the normal cells is linked to the demethylated state of the promoter $\mathrm{CpG}$ island in the HCC tissues. The MAGEA1 gene is such an example, expression of which is off in the normal hepatocytes and on in HCC[31]. Correlating well with such an expression profile, we in deed found that the promoter $\mathrm{CpG}$ island of the MAGEA1 (panel 13, Fig 1) was fully methylated in the normal liver tissue, became unmethylated at a similar frequency in $18 / 28$ (64\%) and 21/28 (75\%) in each of the paired HCC tissue samples, respectively. Judged by the lack of the significance difference $(\mathrm{c} 2=0.76, \mathrm{P}=0.382)$, the demethylation of the promoter $\mathrm{CpG}$ island may more likely to be an early phase event of HCC carcinogenesis.

\section{The stage-specific nature of the HCC associated} changes in the methylation profiles of the promoter CpG islands of genes

It has been well recognized that the so-called noncancerous cells defined under microscope may have already suffered some genetic lesions as have the corresponding cancerous tissues, theoutcome of the earlier events of carcinogenesis. Inclusion of the neighboring non-cancerous tissue in this study made it possible to analyzed our results from the stage-specific perspective of carcinogenesis. As shown in Tab 3, the following genes exhibited a similar frequency in changes of methylation pattern in the HCC tissues and the neighboring non-cancerous tissues from the pattern in the normal liver tissues from health volunteers: ABO $(9 / 28,32 \% ; 14 / 28$, $\left.50 \% ; x^{2}=1.845, \mathrm{P}=0.174\right), \mathrm{CSPG} 2(1 / 28,4 \% ; 5 / 28$, $\left.18 \%, x^{2}=2.987, \mathrm{P}=0.084\right)$, GALR2 $(2 / 28,7 \% ; 6 / 28$, $\left.21 \% ; x^{2}=2.292, \mathrm{P}=0.13\right)$, MT1A $(2 / 28,7 \%, 3 / 28,11 \%$; $\left.x^{2}=0.216, \mathrm{P}=0.642\right)$, MYOD $1(15 / 28,54 \% ; 15 / 28,54 \%$; $\mathrm{P}=1), \mathrm{p} 57 \mathrm{KIP} 2\left(2 / 28,7 \% ; 4 / 28,14 \% ; x^{2}=0.707, \mathrm{P}=0\right.$. $388)$, and WT1 $\left(4 / 28,14 \% ; 8 / 28,29 \% ; x^{2}=1.697, \mathrm{P}=0\right.$. $193)$ as well as the MAGEA1 with having the HCC specific demethylation $\left(18 / 28,64 \% ; 21 / 28,75 \% ; x^{2}=0.76\right.$, $\mathrm{P}=0.383$ ). Three of the four genes studied previously[27] displayed a similar pattern. They were: the RASSF1a (24/29, 79\%; 29/29, 100\%; P=0.085), CDH13 (5/29, 17\%; $\left.6 / 29,20 \%, x^{2}=0.112, \mathrm{P}=0.738\right)$; and CASP8 $(21 / 21$, $100 \% ; 21 / 21,100 \% ; \mathrm{P}=1)$. The rest fell into the second category. They are the genes encoding AR (12/28, 43\%; $\left.20 / 29,71 \% ; x^{2}=4.667, \mathrm{P}=0.031\right)$, cyclin a1 $(8 / 28,29 \%$; 
$\left.15 / 28,54 \% ; \quad x^{2}=3.615,0.057\right)$, DBCCR $1(3 / 28,11 \%$; $\left.16 / 28,57 \% ; \quad x^{2}=13.462, \mathrm{p}<0.001\right)$, IRF7 $(2 / 28,7 \% ; 12 /$ $\left.28,43 \% ; \quad x^{2}=9.524, \mathrm{P}=0.002\right)$, OCT6(14/28, 50\%; 23/28, $\left.82 \% ; x^{2}=6.452, \mathrm{P}=0.011\right)$, and $\mathrm{p} 73(10 / 28,36 \% ; 19 / 28$, $\left.68 \% ; x^{2}=5.793, \mathrm{P}=0.016\right)$. The corresponding figures of the p16INK4a in the previously study [27] were $6 / 29$, $20 \%$, and $16 / 29,55 \%\left(x^{2}=7.323, \mathrm{P}=0.007\right)$. If the neighboring non-cancerous tissue may indeed have already suffered from the early stage genetic and/or epigenetic lesions during carcinogenesis, the HCC specific methylation changes of the ABO, CSPG2, GALR2, MT1A, MYOD1, WT1, MAGEA1, RASSF1a, CDH13 and CASP8 genes occurred at the early stage of the HCC carcinogenesis. On the contrary, the changes in the methylation pattern of the AR, cyclin a1, DBCCR1, IRF7, OCT6, p73, and p16 ${ }^{\mathrm{INK} 4 \mathrm{a}}$ genes was likely to be the late phase event of HCC carcinogenesis. The implication of this new analysis in the HCC remains to be explored in the future.

\section{Association studies of the methylation profiles of the} genes with the clinical-pathological parameters of $\mathrm{HCC}$

After completing the information-gathering of the methylation profiles of forty four genes ( twenty four genes in this report and twenty genes in the previous report [27]) it naturally follows to identify the association between the HCC changes in the methylation of each target with any given clinical-pathological parameters. By a stringent statistic evaluation with both $x^{2}$ and $\mathrm{P}$ tests, we looked for the association between the HCC specific methylation changes of each of the nineteen genes (including four genes in the previous study, 1) and various clinical-pathological parameters. Probably due to the relatively smaller size of patient samples, few association survived from such a scrutiny.

HCC is classified into two major subgroups, those associated with cirrhosis and those without, which differ from both pathological processes as well as the etiological profiles[63,64]. Cirrhosis is a significant pre-HCC pathologic lesion and can be easily diagnosed by the noninvasive ultrasound method. In this connection, the hypermethylated cyclin a1 gene occurred more frequently in the non-cirrhosis HCC group $(10 / 13,76.9 \%)$ than in the cirrhosis HCC group $\left(5 / 15,20 \%, x^{2}=3.615, \mathrm{P}=0\right.$. 057). On the contrary, the hypermethylated p16INK4a gene was more prevalent in cirrhosis HCC patients (12/ $16,75 \%)$ than the non-cirrhosis HCC patients $(4 / 13,30$. $\left.3 \%, x^{2}=7.323, \mathrm{P}=0.007\right)$. Although the underlying mechanisms whereby such a cirrhosis based differential methylation profile has been brought about, it's value for the prognostic evaluation of the clinical treatment of the HCC patients should not be overlooked. Furthermore, it is anticipated that more associations between the methylation of any given targets and the clinical-pathological indicators will be discovered when more HCC patients are subjected to such a study in future.

\section{The concordant methylation behavior of the promoter}

$C p G$ islands of the genes in HCC

\begin{tabular}{|c|c|c|c|c|}
\hline \multicolumn{5}{|c|}{ The early stage-specific change in methylation } \\
\hline & $\mathrm{N} / \mathrm{M}$ & $\mathrm{C} / \mathrm{M}$ & $x^{2}$ & P \\
\hline ABO & $9-19 / 28$ & $14-14 / 28$ & 1.845 & 0.174 \\
\hline CASP8 & $21 / 21$ & $21 / 21$ & & 1.000 \\
\hline $\mathrm{CDH} 13$ & $5-24 / 29$ & $6-23 / 29$ & 0.112 & 0.738 \\
\hline CSPG2 & $1-27 / 28$ & $5-23 / 28$ & 2.987 & 0.084 \\
\hline GALR2 & $2-26 / 28$ & $6 \cdot 22 / 28$ & 2.292 & 0.130 \\
\hline MAGEAI & $18-10 / 28$ & $21-7 / 28$ & 0.760 & 0.383 \\
\hline MTIA & $2-26 / 28$ & $3-25 / 28$ & 0.216 & 0.642 \\
\hline MYOD1 & $15 / 28$ & $15 / 28$ & & 1.000 \\
\hline $\mathrm{p} 57^{\mathrm{k} 1 P 2}$ & $2-26 / 28$ & $4-24 / 28$ & 0.747 & 0.388 \\
\hline RASSFIa & $24-5 / 29$ & $29-0 / 29$ & (4) & 0.085 \\
\hline WT1 & $4-24 / 28$ & $8-20 / 28$ & 1.697 & 0.193 \\
\hline \multicolumn{5}{|c|}{ The late stage-specific changes in methylation } \\
\hline & $\mathrm{N} / \mathrm{M}$ & $\mathrm{C} / \mathrm{M}$ & $x^{2}$ & $\mathbf{P}$ \\
\hline AR & $12-16 / 28$ & $20-8 / 28$ & 4.667 & 0.031 \\
\hline cyclin al & $8-20 / 28$ & $15-13 / 28$ & 3.615 & 0.057 \\
\hline DBCCR 1 & $3-25 / 28$ & $16-12 / 28$ & 13.462 & $<0.001$ \\
\hline IRF7 & $2-26 / 28$ & $12-16 / 28$ & 9.524 & 0.002 \\
\hline OCT6 & $14-14 / 28$ & $23-5 / 28$ & 6.452 & 0.011 \\
\hline p16 $6^{1 \times K+s}$ & $6-23 / 29$ & $16-13 / 29$ & 7.323 & 0.007 \\
\hline$p^{73}$ & $10-18 / 28$ & $19-9 / 28$ & 5.793 & 0.016 \\
\hline
\end{tabular}

Tab 3, The stage-specific changes in the methylation profiles of genes during carcinogenesis. By stringent statistic analyses ( $c^{2}$ and $p$ value), the difference in occurrences of DNA methylation changes between the neighboring normal tissues $(\mathrm{N})$ and the HCC tissues $(\mathrm{C})$ has been evaluated. a), lists the genes where no significant difference were detected, indicating these changes in the methylation profile an early stage-specific event, whereas the b) list the genes with the significant differences were detected, with a close association with the late stage of HCC formation. In column 2 and 3, a-b/c refers to the number of the methylated -unmethylated cases/the total cases (Except for the MAGE1A gene, where the order of $a-b$ is reversed). $\mathrm{NM}$, refers to the methylated cases in the neighboring non-cancerous tissue; and CM the methylated cases in the HCC tissues. N.B., Due to the particular feature in the RASSF1A, where it is $100 \%$ hyper-methylated in HCC tissue, it is beyond the capacity of such statistic analyses. The intuitive decision was supported by the same analysis with assumed 1/29 sample were not hyperme-thylated in HCC. 
http://www.cell-research.com

As far as the number of the genes is concerned, our present studies are likely to be most comprehensive in the teen genes in the HCC group and in various sub-groups for the first time. Both occurrence and frequencies of the HCC specific changes in various subsets of two upward to nine genes among the nineteen genes (including four genes in previous study[27]) with the best sub-set selection method[29]. Although, CASP8 was hypermethylated in $21 / 29$ samples tested, the remaining eight samples failed to be informative, we excluded the CASP8 gene from this analysis. As shown in Tab 5, the frequency of the two gene (the hypermethylated OCT6 and RASSF1a) was $82 \%$ and of three gene (the former two plus the hypermethylated $\mathrm{p} 73$ ) was $68 \%$ and of four gene subsets (the former three plus the demethylated HCC field, to our best knowledge, which enable us to look into the concordant methylation behavior of the nine-

\begin{tabular}{lrrrr}
\hline & cirrhosis & Non-cirrhosis & $\chi^{2}$ & $\mathrm{P}$ \\
\hline pl6 $^{\mathrm{INK4a}}$ & $4-12 / 16$ & $9-4 / 13$ & 5.673 & 0.017 \\
cyclin al & $10-5 / 15$ & $3-10 / 13$ & 5.320 & 0.021
\end{tabular}

Tab 4. The cirrhosis-associated hypermethylation of the genes in HCC. By stringent statistic analyses ( $c^{2}$ and $\mathrm{P}$ value), the frequencydifferences in changes in DNA methylation of the genes between the cirrhosis and non-cirrhosis patient groups have been analyzed and presented.

MAGEA1) was $54 \%$ in the HCC patient group. In the cirrhosis-HCC groups, the frequency of the two genes (the hypermethylated RASSF1a and OCT6) was $87 \%$, and three gene sub-sets (the former two genes plus the p16 $6^{\mathrm{INK} 4 \mathrm{a}}$ or $\mathrm{p} 73$ ) was $73 \%$. The corresponding pattern of the non-cirrhosis patient group was different, the frequency of the two genes (the hypermethylated RASSF1a plus the hypomethylated MAGEA1 or the hypermethylated OCT6 or the hypermethylated cyclin a1) was

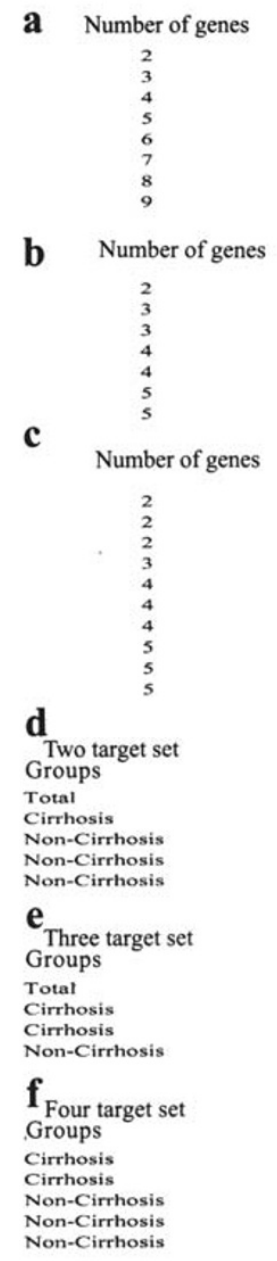

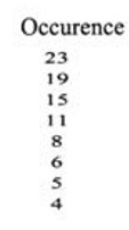
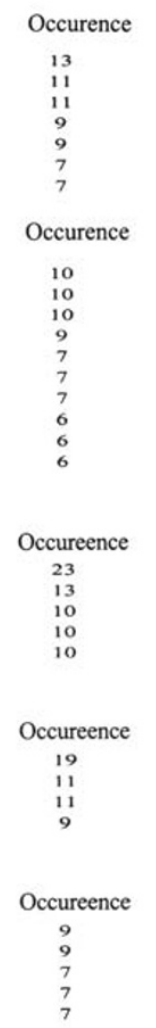
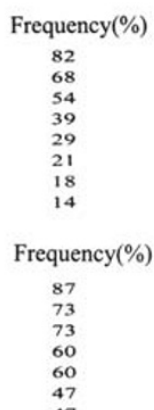

Frequency(\%)
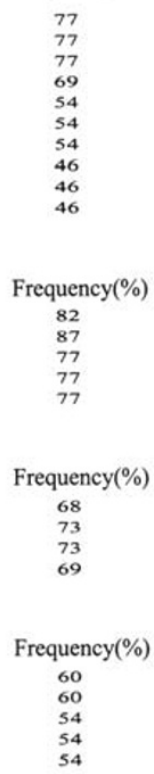

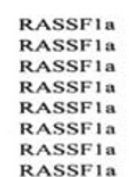

RASSF1a

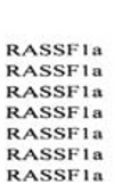

RASSF1a$$
\text { Re }
$$

RASSF1a MAGEA1 $\begin{array}{ll}\text { RASSF1a } & \text { OCT6 } \\ \text { RASSFla } & \text { cyclinal }\end{array}$ $\begin{array}{ll}\text { RASSF1a } & \text { cyclinal } \\ \text { RASSF1a } & \text { OCT6 } \\ \text { RASSF1a } & \text { OCT6 }\end{array}$ RASSF1a RASSF1a RASSF 1a OCT6 $\begin{array}{ll}\text { RASSF1a } & \text { OCT6 } \\ \text { RASSF1a } & \text { OCT6 }\end{array}$ OCT6
OCT6
OCT6
OCT6
OCT6
OCT6
OCT6
OCT6 The genes in sub-set

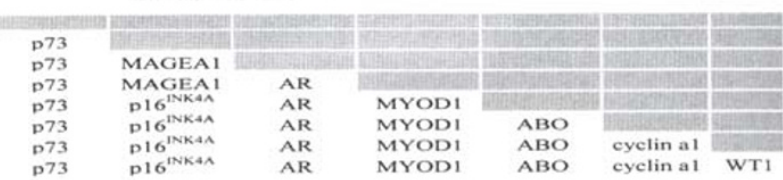

The genes in sub-set

OCT6 iㅐ aㅏ

OCT6

OCT6

OCT6

OCT6 $D 16^{1 N 24 x}$
p73 D16 INK4A

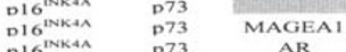

The genes in sub-set

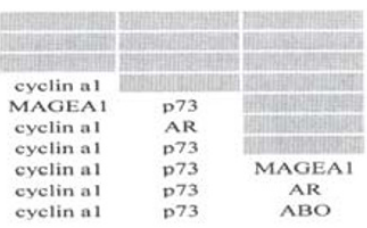

The genes in sub-set RASSF1a OCT6 RASSFIa OCT6 RASSF1a MAGEA RASSF1a OCT6
RASSF1a eyelinal

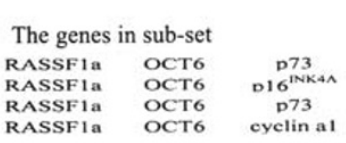

The genes in sub-set $\begin{array}{llcl}\text { RASSF1a } & \text { OCT6 } & \text { DI6INKAA } & \text { AR } \\ \text { RASSF1a } & \text { OCT6 } & \text { D16 } 1 \text { INKAA } & \text { p73 } \\ \text { RASSF1a } & \text { OCT6 } & \text { MAGEA1 } & \text { D73 } \\ \text { RASSF1a } & \text { OCT6 } & \text { cyclina1 } & \text { AR } \\ \text { RASSF1a } & \text { OCT6 } & \text { cyclinal } & \text { p73 }\end{array}$

Tab 5. The summary of the concordant methylation behavior of the hypermethylated genes. Base upon the best sub-set selection method, the gene subsets of two to nine genes in the HCC or two to five genes in the cirrhosis and non-cirrhosis subgroups were presented. a), the HCC as a whole; b), The non-cirrhosis patient group, c), the cirrhosis patient group; d-f), the summary of the two, three and four gene subsets, respectively. 
$77 \%$ and of the three gene sub-sets (the hypermethylated RASSF1a plus hypermethylated OCT6 and cyclin a1) was $69 \%$.

\section{SUMMARIES}

Tumor associated changes in the methylation profiles of the promoter $\mathrm{CpG}$ islands of, chiefly, the suppressor genes have been well documented, suggesting the possible role of the epigenetic mechanisms for gene inactivation, as an alternative to the genetic lesions, including deletion and mutation in tumors[7,65,66]. Therefore, methylation profiling would be a useful information gathering process for a better understanding of carcinogenesis as well as the better diagnostic, prognostic and even therapeutic measures against tumors. In this study, we expand further the list of targets from twenty [27] to forty four known genes for methylation profiling in the normal healthy liver, HCC tissues and the paired normal tissues, representing a most comprehensive survey in the HCC.

Finally, the concordant methylation profiles of these nineteen genes summarized above (d-f, Tab 5) may be useful as the prognostic, possibly the diagnostic biomarkers for HCC. They may serve the good epigenetic markers to detect tumor cells from biopsies, serum, and so forth, if both sensitivity and specificity of these assays can be satisfactorily established. It may also be useful to determine the methylation status of these markers in circulating tumor cells in blood or predict the sensitivity to chemotherapy, and overall therapeutic outcomes of the HCC patients differing in cirrhosis status, grading and other clinical-pathological profiles.

\section{ACKNOWLEDGEMENTS}

Thanks are due to Jian Guo CHEN, Li Sheng ZHANG, Meng Chao WU and Su Shen ZHEN for providing the patient's samples, Jian Ren GU for his support at the early stage of this project and Jian Xin and Jianyin Guo for their assistance in the statistic treatment of the data. This work was supported by the National High Technology Research and Development Program of China (863 Program) (2001AA217011, 2002AA2Z3352), the Major State Basic Research Development Program of China (973 Program) (G1998051004), and the Science Foundation of Shanghai Municipal Government (02DJ14056) to JingDe ZHU.

\section{REFERENCES}

1 Ferlay J, F Bray, P Pisani and D M Parkin. GOBOCAB 2000 Cancer Incidence, Mortality and Prevalence Worldwide,. Lyon: IARC Scienctific Publications, IARC Press, 2001

2 Parkin D, P Pisani and J Ferlay. Global cancer statistics. CA Cancer J. Clin., 1999; 49:33-64.

3 Cancer Incidence and Mortality in China, 1993-1997 (Selected Cities and Counties). Beijing: China Publishing House of Medical Sciences and Technologies, 1998

4 Feitelson M A, B Sun, N L Satiroglu Tufan, J Liu, J Pan and Z Lian. Genetic mechanisms of hepatocarcinogenesis. Oncogene 2002; 21(16):2593-604.

5 Kim J W and X W Wang. Gene expression profiling of preneoplastic liver disease and liver cancer: a new era for improved early detection and treatment of these deadly diseases? Carcinogenesis 2003; 24(3):363-9.

6 Wang X W, S P Hussain, T I Huo, et al. Molecular pathogenesis of human hepatocellular carcinoma. Toxicology 2002; 181-182:43-7.

7 Baylin S and T H Bestor. Altered methylation patterns in cancer cell genomes: cause or consequence? Cancer Cell 2002; 1(4):299305.

8 Esteller M. Relevance of DNA methylation in the management of cancer. Lancet Oncol 2003; 4(6):351-8.

9 Esteller M and J G Herman. Cancer as an epigenetic disease: DNA methylation and chromatin alterations in human tumours. J Pathol 2002; 196(1):1-7.

10 Jones P A and D Takai. The role of DNA methylation in mammalian epigenetics. Science 2001; 293(5532):1068-70.

11 Jaenisch R and A Bird. Epigenetic regulation of gene expression: how the genome integrates intrinsic and environmental signals. Nat Genet 2003; 33 Suppl:245-54.

12 Jones P A. Epigenetics in carcinogenesis and cancer prevention. Ann N Y Acad Sci 2003; 983:213-9.

13 Geiman T M and K D Robertson. Chromatin remodeling, histone modifications, and DNA methylation-how does it all fit together? J Cell Biochem 2002; 87(2):117-25.

14 Feninberg A. Cancer epigenetics takes center stage. Proc. Natl. Acad. Sci. U S.A. 2001; 98(2):392-4.

15 Eden A, F Gaudet, A Waghmare and R Jaenisch. Chromosomal instability and tumors promoted by DNA hypomethylation. Science 2003; 300(5618): 455 .

16 Gaudet F, J G Hodgson, A Eden, et al. Induction of tumors in mice by genomic hypomethylation. Science 2003; 300(5618): 489-92.

17 Chen R Z, U Pettersson, C Beard, L Jackson-Grusby and R Jaenisch. DNA hypomethylation leads to elevated mutation rates. Nature 1998; 395(6697):89-93.

18 Esteller M, M F Fraga, M Guo, et al. DNA methylation patterns in hereditary human cancers mimic sporadic tumorigenesis. Hum Mol Genet 2001; 10(26):3001-7.

19 Zochbauer-Muller S, K M Fong, A K Virmani, J Geradts, A F Gazdar and J D Minna. Aberrant promoter methylation of multiple genes in non-small cell lung cancers. Cancer Res 2001; 61 (1):249-55. 
20 Rosas S L, W Koch, M G da Costa Carvalho, et al. Promoter hypermethylation patterns of p16, O6-methylguanine-DNAmethyltransferase, and death-associated protein kinase in tumors and saliva of head and neck cancer patients. Cancer Res 2001; 61 (3):939-42.

21 Foster S A, D J Wong, M T Barrett and D A Galloway. Inactivation of p16 in human mammary epithelial cells by $\mathrm{CpG}$ island methylation. Mol Cell Biol 1998; 18(4):1793-801.

22 Cui H, P Onyango, S Brandenburg, Y Wu, C L Hsieh and A P Feinberg. Loss of imprinting in colorectal cancer linked to hypomethylation of H19 and IGF2. Cancer Res 2002; 62(22): 6442-6.

23 Cho B, H Lee, S Jeong, et al. Promoter hypomethylation of a novel cancer/testis antigen gene CAGE is correlated with its aberrant expression and is seen in premalignant stage of gastric carcinoma. Biochem Biophys Res Commun 2003; 307(1):52-63.

24 Hattori M, H Sakamoto, K Satoh and T Yamamoto. DNA demethylase is expressed in ovarian cancers and the expression correlates with demethylation of $\mathrm{CpG}$ sites in the promoter region of c-erbB-2 and survivin genes. Cancer Lett 2001; 169(2): 155-64.

25 Hoare S F, L A Bryce, G B Wisman, et al. Lack of telomerase RNA gene hTERC expression in alternative lengthening of telomeres cells is associated with methylation of the hTERC promoter. Cancer Res 2001; 61(1):27-32.

26 Toyota M, N Ahuja, M Ohe-Toyota, J G Herman, S B Baylin and J P Issa. CpG island methylator phenotype in colorectal cancer. Proc Natl Acad Sci U S A 1999; 96(15):8681-6.

$27 \mathrm{Yu}$ J, M Ni, J Xu, et al. Methylation profiling of twenty promoter-CpG islands of genes which may contribute to hepatocellular carcinogenesis. BMC Cancer 2002; 2(1):29.

28 Liver Cancer Study Group of Japan. TNM classification for hepatocellular carcinoma by Liver Cancer Study group. World J Surg 1989; 13:212.

29 Miller A J. Subset Selection in Regression. New York Champman and Hall 1990.

30 Liu Q, Wang, W, \& eds. Liver Cancer. Beijing: People's Medical Publishing House, 2000

31 Mou D C, S L Cai, J R Peng, et al. Evaluation of MAGE-1 and MAGE-3 as tumour-specific markers to detect blood dissemination of hepatocellular carcinoma cells. Br J Cancer 2002; 86(1): 110-6.

32 Yin $\mathrm{H}$ and $\mathrm{K}$ Blanchard. DNA methylation represses the expression of the human erythopoietin gene by two diffferent mechanisms. Blood 2000; 95(1):111-9.

33 Sauter $\mathrm{P}$ and $\mathrm{P}$ Matthias. Coactivator OBF-1 makes selective contacts with both the POU-specific domain and the POU homeodomain and acts as a molecular clamp on DNA. Mol Cell Biol 1998; 18(12):7397-409.

34 Iwamoto S, D A Withers, K Handa and S Hakomori. Deletion of A-antigen in a human cancer cell line is associated with reduced promoter activity of $\mathrm{CBF} / \mathrm{NF}-\mathrm{Y}$ binding region, and possibly with enhanced DNA methylation of A transferase promoter. Glycoconj J 1999; 16(10):659-66.

35 Chen B, P Dias, J J Jenkins, 3rd, V H Savell and D M Parham. Methylation alterations of the MyoD1 upstream region are pre- dictive of subclassification of human rhabdomyosarcomas. Am J Pathol 1998; 152(4):1071-9.

36 Hutchins A S, A C Mullen, H W Lee, et al. Gene silencing quantitatively controls the function of a developmental trans-activator. Mol Cell 2002; 10(1):81-91.

37 Reeben M, S Myohanen, M Saarma and H Prydz. Sequencing of the rat light neurofilament promoter reveals differences in methylation between expressing and non-expressing cell lines, but not tissues. Gene 1995; 157(1-2):325-9.

38 Kibel A S, M Christopher, D A Faith, G S Bova, P J Goodfellow and W B Isaacs. Methylation and mutational analysis of p27 (kip1) in prostate carcinoma. Prostate 2001; 48(4):248-53.

39 Li Y, H Nagai, T Ohno, et al. Aberrant DNA methylation of p57 (KIP2) gene in the promoter region in lymphoid malignancies of B-cell phenotype. Blood 2002; 100(7):2572-7.

40 Watanabe T, H Huang, M Nakamura, et al. Methylation of the p73 gene in gliomas. Acta Neuropathol (Berl) 2002; 104(4):35762.

41 Laux D E, E M Curran, W V Welshons, D B Lubahn and T H Huang. Hypermethylation of the Wilms' tumor suppressor gene $\mathrm{CpG}$ island in human breast carcinomas. Breast Cancer Res Treat 1999; 56(1):35-43

42 Wang S, T Hashemi, S Fried, A L Clemmons and B E Hawes. Differential intracellular signaling of the GalR1 and GalR2 galanin receptor subtypes. Biochemistry 1998; 37(19):6711-7.

43 Usmani B A, R Shen, M Janeczko, et al. Methylation of the neutral endopeptidase gene promoter in human prostate cancers. Clin Cancer Res 2000; 6(5):1664-70.

44 Venkataraman G M, M Yatin, R Marcinek and K B Ain. Restoration of iodide uptake in dedifferentiated thyroid carcinoma: relationship to human $\mathrm{Na}+$ /I-symporter gene methylation status. J Clin Endocrinol Metab 1999; 84(7):2449-57.

45 Cui J, L R Rohr, G Swanson, V O Speights, T Maxwell and A R Brothman. Hypermethylation of the caveolin-1 gene promoter in prostate cancer. Prostate 2001; 46(3):249-56.

46 Toyota M, C Ho, N Ahuja, et al. Identification of differentially methylated sequences in colorectal cancer by methylated $\mathrm{CpG}$ island amplification. Cancer Res 1999; 59(10):2307-12.

47 Sasaki M, Y Tanaka, G Perinchery, et al. Methylation and inactivation of estrogen, progesterone, and androgen receptors in prostate cancer. J Natl Cancer Inst 2002; 94(5):384-90.

48 Muller C, C Readhead, S Diederichs, et al. Methylation of the cyclin A1 promoter correlates with gene silencing in somatic cell lines, while tissue-specific expression of cyclin A1 is methylation independent. Mol Cell Biol 2000; 20(9):3316-29.

49 Rachmilewitz E A. The role of methylation in CML. Przegl Lek 2000; 57 Suppl 1:25-6.

50 Habuchi T, M Luscombe, P A Elder and M A Knowles. Structure and methylation-based silencing of a gene (DBCCR1) within a candidate bladder cancer tumor suppressor region at 9q32-q33. Genomics 1998; 48(3):277-88.

51 Ghoshal K, S Majumder, Z Li, X Dong and S T Jacob. Suppression of metallothionein gene expression in a rat hepatoma because of promoter-specific DNA methylation. J Biol Chem 2000; 275(1):539-47.

52 Yuasa Y. DNA methylation in cancer and ageing. Mech Ageing 
Dev 2002; 123(12):1649-54.

53 Richardson B. Impact of aging on DNA methylation. Ageing Res Rev 2003; 2(3):245-61.

54 Yamanaka M, M Watanabe, Y Yamada, et al. Altered methylation of multiple genes in carcinogenesis of the prostate. Int $\mathrm{J}$ Cancer 2003; 106(3):382-7.

55 Tavian D, G De Petro, A Pitozzi, N Portolani, S M Giulini and S Barlati. Androgen receptor mRNA under-expression in poorly differentiated human hepatocellular carcinoma. Histol Histopathol 2002; 17(4):1113-9.

56 Dong S, J C Pang, J Hu, L F Zhou and H K Ng. Transcriptional inactivation of TP73 expression in oligodendroglial tumors. Int J Cancer 2002; 98(3):370-5.

57 Loiseau H, J Arsaut and J Demotes-Mainard. p73 gene transcripts in human brain tumors: overexpression and altered splicing in ependymomas. Neurosci Lett 1999; 263(2-3):173-6.

58 Satoh Y, T Nakagawachi, H Nakadate, et al. Significant Reduction of WT1 Gene Expression, Possibly Due to Epigenetic Alteration in Wilms' Tumor. J Biochem (Tokyo) 2003; 133(3):303-8.

59 Tomita Y, V Bilim, N Hara, T Kasahara and K Takahashi. Role of IRF-1 and caspase-7 in IFN-gamma enhancement of Fas-medi- ated apoptosis in ACHN renal cell carcinoma cells. Int J Cancer 2003; 104(4):400-8.

60 Detjen K M, D Murphy, M Welzel, K Farwig, B Wiedenmann and S Rosewicz. Downregulation of p21(waf/cip-1) mediates apoptosis of human hepatocellular carcinoma cells in response to interferon-gamma. Exp Cell Res 2003; 282(2):78-89.

$61 \mathrm{Lu}$ R, W C Au, W S Yeow, N Hageman and P M Pitha. Regulation of the promoter activity of interferon regulatory factor-7 gene. Activation by interferon snd silencing by hyperme-thylation. J Biol Chem 2000; 275(41):31805-12.

62 Ehrlich M. DNA methylation in cancer: too much, but also too little. Oncogene 2002; 21(35):5400-13.

$63 \mathrm{Su}$ Q and P Bannasch. Relevance of hepatic preneoplasia for human hepatocarcinogenesis. Toxicol Pathol 2003; 31(1):12633.

64 Kopp-Schneider A. Biostatistical evaluation of focal hepatic preneoplasia. Toxicol Pathol 2003; 31(1):121-5.

65 Baylin S B and J G Herman. DNA hypermethylation in tumorigenesis: epigenetics joins genetics. Trends Genet 2000; 16 (4):168-74.

66 Bestor T H. Unanswered questions about the role of promoter methylation in carcinogenesis. Ann N Y Acad Sci 2003; 983:22-7. 